Edu Consilium: Jurnal BK Pendidikan Islam

Vol. 3, No. 1, 2022, hlm. 89-100

DOI: $10.19105 /$ ec.v1i1.1808

ISSN 2503-3417 (online)

ISSN 2548-4311 (cetak)

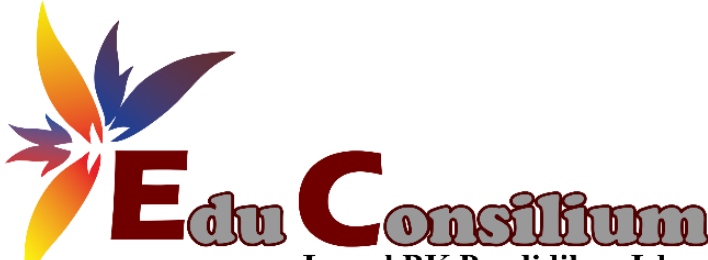

Jurnal BK Pendidikan Islam

\title{
PERANAN BIMBINGAN KELOMPOK DENGAN TEKNIK FOCUS GROUP DISSCUSSION UNTUK MENINGKATKAN KETRAMPILAN LEARNING TIME MANAGEMENT PADA PESERTA DIDIK
}

\author{
${ }^{1}$ Awalin Widyastuti, ${ }^{2}$ Kun Widya Nurfiani, ${ }^{3}$ Glonda Aji Desembra \\ ${ }^{1,2,3}$ Program Studi Bimbingan dan Konseling, Universitas Slamet Riyadi Surakarta, Indonesia \\ *awalinwidyastuti77@gmail.com
}

\begin{tabular}{ll}
\hline & Abstract \\
\hline Keywords: & Based on the importance of the study and time management skills learned that should \\
Grouup & be owned by students. The purpose of this research is to know and get the level of \\
Guidance, & development of information sebarapa great learning time management skills students \\
Focus Group & after treatment guidance of the focus group discussion. The research is reading \\
Disscucion & literature research with the use of the relevant and available related to the topic \\
Techniques, & discussed in research . The journal article sample taken by using screening process of \\
Learning & as many as 5 . The research uses design table of extracting data from 5 articles journals \\
Time & used as the literature study to do an analysis of the discussion . Studies library show \\
Management. & that there has been increasing significant learning time management services group \\
& having given guidance technique using focus discussion group . It can be concluded \\
& that "any impact positive and significant on the skills students learn in the \\
& management of time.
\end{tabular}

\begin{tabular}{ll}
\hline & Abstrak \\
\hline Kata Kunci: & Penelitian ini dilatarbelakangi oleh pentingnya tingkat keterampilan manajemen \\
Bimbingan & waktu belajar yang harus dimiliki oleh peserta siswa. Tujuan penelitian ini adalah \\
Kelompok, Teknik & untuk meneliti dan mendapatkan informasi sebarapa besar tingkat perkembangan \\
Focus Group & keterampilan learning time management peserta didik setelah mendapatkan layanan \\
Dissussion, & Manajemen Waktu \\
Belajar & bimbingan kelompok dengan tehnik focus group discussion. Metode penelitian ini \\
& adalah penelitian kepustakaan dengan menggunakan sumber bacaan yang relevan dan \\
& tersedia terkait dengan topik yang dibahas dalam penelitian. Sampel artikel jurnal \\
& yang diambil sebanyak 5 dan menggunakan proses screening. Desain penelitian \\
& menggunakan table ekstraksi data dari 5 artikel jurnal yang digunakan sebagai studi \\
& pustaka untuk dilakukan analisis uraian pembahasan. Hasil studi pustaka \\
& menunjukkan bahwa peningkatan manajemen waktu belajar yang berarti terjad \\
& (Gunawan 2018) apabila setelahnya diberikan layanan bimbingan kelompok dengan \\
& menggunakan tehnik focus discussion group. Dapat disimpulkan bahwa "ada \\
& pengaruh positif yang signifikan terhadap keterampilan peserta didik dalam \\
& manajemen waktu belajar".
\end{tabular}

CEdu Consilium: Jurnal Bimbingan dan Konseling Pendidikan Islam

Institut Agama Islam Negeri Madura, Indonesia

\section{PENDAHULUAN}

Maryati (2019) mengemukakan bahwa keberhasilan pendidikan secara praktis dimulai dengan tingkat keberhasilan proses belajar oleh peserta didik. Ada beberapa factor yang 
berpengaruh terhadap kesulitan belajar peserta didik baik itu secara internal maupun secara eksternal seperti, kondisi lingkungan keluarganya dan lingkungan sebayanya.

Layanan bimbingan dan konseling di sekolah dirancang untuk memberi bantuan terhadap siswa dalam meningkatkan kualitas kehidupan pribadi, sosial, kegiatan belajar, dan perencanaan maupun peningkatan profesional mereka. Layanan bimbingan dan konseling mendorong pengembangan pribadi, kelompok dan/atau klasik siswa sesuai dengan kebutuhan, potensi, bakat, minat, perkembangan, kondisi, dan peluang mereka. Gunawan (2018) menyatakan bahwa permasalahan yang dialami oleh seseorang dapat diatasi dengan layanan ini. Layanan informasi, layanan orientasi, penguasaan konten, penenmpatan dan penyaluran, bimbingan kelompok, konseling kelompok, konseling individdu, serta beliau menjelaskan bahwa layanan bimbingan daan konseling dilengkapi dengan dua jenis layanan yaitu konsultasi dan mediasi. Layanan Bimbingan kelompok menjadi salah satu program layanan bimbingan dan konseling yang menjadi primadona. (NISA BELLA 2019) mengemukakan bahwa pencegahan permasalahan pada individu melalui informasi yang disusun dan diambil dengan keputusan yang tepat merupakan peran dari bimbingan kelompok. Layanan bimbingan kelompok ini begitu digemari oleh guru bimbingan dan konseling karena penyampaian pandangan dan penyelesaian masalah dapat diselesaikan secara bersama oleh setiap anggta dengan memanfaatkan dinamika kelompok. Kondisi idealnya ialah ketika peserta didik mampu melaksanakan bimbinga kelompok dan memraktekkannya dalam merubah perilaku negative menjadi perilaku yang positif.

Permasalahan siswa yang sering terjadi dalam lingkup sekolah adalah cara mereka mengatur waktu, bagaimana mereka memanfaatkan waktu mereka untuk belajar. Ketidakmampuan dan kurangnya pemahaman tentang manajemen jam siswa dapat berdampak buruk pada siswa. Artinya, hal yang membuat siswa kurang disiplin yaitu tidak dapat menyesuaikan waktu untuk kegiatan akademik dengan kegiatan non-akademik, sehingga mengakibatkan kurangnya kedisiplinan di kalangan siswa. (Ulfa Luthfiyanti, Supardi 2020). Memahami Manajemen Waktu Melatih Siswa Mengembangkan Kepribadian Disiplin Siswa Membutuhkan Pelatihan Mengatur Jadwal Harian.(Wahyu Riyanto, Yusmansyah 2020). Dan terdapat jenis bimbingan kelompok yang digunakan untuk meningkatkan learning time management pada peserta didik, salah satunya menggunakan Teknik Focus Group Discussion.

Ada beberapa cara bagi siswa untuk belajar mengatur waktu, salah satunya adalah dengan menggunakan teknik FGD. Situmorang (2019:226) mengemukakan bahwa tingkat 
kecemasan mahasiswa dapat menjadi lebih rendah karena teknik Focus Group Disscussion. Beliau juga menjelaskan bahwa FGD adalah suatu metode penyelesaian permasalahan yang dilakukan dengan menggunakan suasana kekeluargaan.

Melalui pemanfaatan teknologi Focus Group Discussion (FGD), diharapkan mahasiswa dapat memperoleh informasi sistematis yang lebih spesifik tentang peran bimbingan dan konsultasi dalam meningkatkan manajemen waktu belajar. Melalui diskusi kelompok terarah, diharapkan topik diskusi bimbingan kelompok dapat memberikan dampak positif yang luas terhadap manajemen waktu siswa.

Pencarian dan pengamatan yang telah dilakukan oleh penulis dalam publikasi ilmiah melalui portal Google Schoolar mendapatkan hasil 10 penelitian yang terkait. Sebagian besar penelitian tersebut masih sangat minim keterbacaannya, Setelah melihat publikasi ilmiah atau artikel dari portal Open Knowledge Maps, masih banyak peneliti yang belum meneliti mengenai bidang ini. Beberapa penelitian sebelumnya sudah melakukan penelitian tentang bimbingan konseling, tetapi banyak penelitian yang belum mengcover peran bimbingan terhadap keterampilan manajemen waktu belajar peserta didik. Sebagian penelitian yang menggunakan peranan bimbingan konseling hanya untuk mengurangi persepsi negative peserta didik. Sebagian besar hasil publikasi penelitian jurnal hanya berisi mengenai peran bimbingan kelompok yang dilakukan secara terfokus untuk merubah persepsi bukan perilaku dan memberikan keterampilan bagi peserta didik.

Salah satu teknik bimbingan kelompok yang mampu memberikan dampak positif bagi keterampilan dan perilaku peserta didik adalah dengan teknik Focus Group Discussion. Bimbingan Kelompok dengan Teknik Focus Group Discusion (FGD) merupakan upaya sistematis untuk dapat berdiskusi kelompok secara terfokus. Focus Group Disscussion begitu spesifik dalam membahas permasalahan-permasalahan untuk dapat mencaapai tujuan yang tepat.

Diskusi kelompok dengan teknik FGD bertujuan agarpeserta didik dapatmencapai kesepakatan tertentu terhadap permasalahan yang dialami dan sesuai peran dari bimbingan konseling. Peneliti dapat memahami alasan, motivasi , argumentasi atau pendapat seseorang untuk mengembangkan keterampilannya melaalui FGD (Fokus Group Discussion). Bimbingan kelompok melalui (Waluyati 2020) teknik Focus Group Discussion masih minim digunakan untuk meningkatkan learning time manajemen peserta didik. Penelitian ini memiliki kebaharuan dalam menyimpulkan dampak peranan bimbingan kelompok dengan teknik FGD atau Focus Group Discussion terhadap keterampilan peningkatan learning time 
manajemen peserta didik. Penelitian ini tentu memiliki dampak positif yang besar bagi pemberian data informasi mengenai peranan bimbingan kelompok melalui teknik Focus Group Discussion dan data informasi mengenai dampak teknik FGD terhadap peningkatan keterampilan leraring time manajemen atau manajemen waktu belajar peserta didik kedepannya.

Isu yang dibahas dalam Focus Group Discussion begitu spesifik karena mencapai suatu tujuan yang tepat. Diskusi kelompok dengan menggunakan teknologi FGD dirancang agar dapat mencapai suatu kesepakatan dari problematika masalah yang dihadapi siswa, terutama berdasarkan peran bimbingan dan konseling. Melalui FGD (focus group discussion), peneliti mendapatkan informasi mengenai alasan, motivasi, dan argument dasar individu seseorang untuk meningkatkan keterampilannya. Teknologi Focus Group Discussion (FGD) bimbingan kelompok belum banyak digunakan untuk meningkatkan manajemen waktu belajar siswa. Penelitian ini merupakan penelitian baru dalam meringkas pengaruh teknologi bimbingan kelompok FGD (Focus Group Discussion) terhadap peningkatan keterampilan manajemen waktu belajar siswa. . Penelitian ini tentu memiliki dampak positif yang besar bagi pemberian data informasi mengenai peranan bimbingan kelompok teknik Focus Group Discussion dan data informasi mengenai dampak teknik FGD terhadap peningkatan keterampilan leraring time manajemen atau manajemen waktu belajar peserta didik kedepannya.

\section{METODE}

Artikel ini menggunakan metode penelitian kepustakaan. Penelitian kepustakaan merupakan studi kepustakaan yang menggunakan sumber bacaan yang relevan dengan topic pembahasan. Sumber bacaan yang digunakan adalah buku maupun artikel jurnal yang sesuai dengan topic pembahasan. Metode penulisan studi pustaka diperoleh dengan menemukan beberapa artikel di website portal sebagai sumber penelitian kepustakaan atau tulisan bacaan. Artikel ini menggunakan studi pustaka untuk memperoleh data, dimana pengaruh coaching terhadap teknik FGD digunakan untuk memberi dampak peningkatan terhadap kemampuan siswa pada manajemen waktu belajarnya.

Data yang diperoleh dari hasil pencarian adalah 10 artikel jurnal. Sumber pencarian artikel jurnal yang digunakan ialah melalui portal Google Schollar dengan kata kunci bimbingan kelompok untuk meningkatkan manajemen waktu peserta didik. Diperoleh 10 artikel jurnal dan terdapat 5 artikel jurnal yang memiliki kesesuaian dengan judul penulisan. 5 
artikel jurnal yang sesuai dengan judul didapatkan setelah melalui proses screening dan artikel jurnal tersebut akan digunakan sebagai sumber bacaan dalam penulisan.

Dari 5 artikel jurnal yang diperoleh, akan digunakan sebagai dasar sumber bacaan untuk melakukan analisis data dalam penulisan. Analisis data dalam penulisan menggunakan artikel jurnal yang sesuai judul dan memiliki kelayakan kriteria, yang kemudian akan dibuat menjadi tabel ekstraksi data. Analisis data dilakukan dengan melakukan uraian pembahasan antara 5 artikel jurnal yang sudah dimuat dalam ekstrasi data dan menjadi sumber bacaan untuk dapat dijadikan sebagai sebuah kesimpulan mengenai hasil dan tingkat keberhasilan dari penelitian terhadap pengaruh bimbinan kelompok terhadap keterampilan manajemen waktu peserta didik.

\section{HASIL}

Berdasarkan 10 artikel yang tampaknya sesuai untuk tujuan penelitian, digunakan sebagai filter untuk mengidentifikasi kesesuaian judul artikel. Setelah direview, terdapat 5 artikel dengan judul yang sama, 5 diantaranya direview berdasarkan kriteria. Referensi tentang strategi pencarian literatur review dapat ditemukan pada Tabel 1.

\begin{tabular}{|lc|}
\hline Mesin pencari & Google Schollar \\
\hline Hasil penelusuran, tahun 2017-2021 & 10 \\
\hline Fulltext.pdf & 7 \\
\hline Judul yang sesuai & 5 \\
\hline Kelayakan sesuai kriteria & 5 \\
\hline Result & 5 \\
\hline
\end{tabular}

Menganalisis lima artikel mengungkapkan bahwa satu artikel menggunakan metode yang digunakan dalam penelitian ini, adalah desain eksperimental kuantitatif yang sebenarnya adalah studi tentang subjek atau penelitian secara individu. Setelah memeriksa kualitas penelitian, 5 artikel dapat diklasifikasikan dengan baik. Kemudian dilaksanakan proses ekstraksi data. Ekstraksi data ini dilakukan dengan cara menganalisis data berdasar dari nama, pengarang, judul, tujuan, metode, penelitian, dan hasil. Artinya, pengelompokan data yang penting dalam sebuah artikel. Hasil ekstraksi data ditunjukkan pada Tabel 2. 


\begin{tabular}{|c|c|c|c|c|c|}
\hline $\begin{array}{c}\text { Penulis / } \\
\text { tahun }\end{array}$ & Judul & Jurnal & Tujuan & Metode & Hasil \\
\hline $\begin{array}{l}\text { Ulfa } \\
\text { Lutfianti, } \\
\text { Supardi, Agus } \\
\text { Setiawan / } \\
2020\end{array}$ & $\begin{array}{l}\text { Pengaruh } \\
\text { layanan } \\
\text { bimbingan } \\
\text { kelompok } \\
\text { dengan } \\
\text { Teknik } \\
\text { simulation } \\
\text { games untuk } \\
\text { meningkatka } \\
\text { n } \\
\text { management } \\
\text { waktu } \\
\text { belajar siswa } \\
\text { kelas XII } \\
\text { SMAN } 9 \\
\text { Semarang }\end{array}$ & $\begin{array}{l}\text { Pedagogi } \\
\mathrm{k} \text { jurnal } \\
\text { Pendidika } \\
\mathrm{n} \text { Vol } 15 \\
\text { No } 2 \text { (27- } \\
35)\end{array}$ & $\begin{array}{lr}\text { mengetahui } \\
\text { tingkat } \\
\text { manajemen } \\
\text { waktu } \\
\text { belajar siswa } \\
\text { kelas XII SMA } \\
\text { Negeri } \\
\text { Semarang }\end{array}$ & $\begin{array}{l}\text { True } \\
\text { experimental } \\
\text { design } \\
\text { dengan } \\
\text { bentuk } \\
\text { pretest- } \\
\text { posttest } \\
\text { control } \\
\text { group } \\
\text { design }\end{array}$ & $\begin{array}{l}\text { ada pengaruh } \\
\text { layanan } \\
\text { bimbingan } \\
\text { kelompok } \\
\text { dengan teknik } \\
\text { simulation } \\
\text { games untuk } \\
\text { meningkatkan } \\
\text { manajemen } \\
\text { waktu siswa } \\
\text { belajar sII } \\
\text { kelas Negeri } \\
\text { SMA Nemarang }\end{array}$ \\
\hline $\begin{array}{l}\text { Yeni Rahma } \\
\text { Nanda, } \\
\text { Syahriman, } \\
\text { Vira Afriyanti } \\
\text { / } 2021\end{array}$ & $\begin{array}{l}\text { Pengaruh } \\
\text { bimbingan } \\
\text { kelompok } \\
\text { dengan } \\
\text { Teknik self } \\
\text { management } \\
\text { terhadap } \\
\text { pemanfaatan } \\
\text { waktu siswa } \\
\text { kelas IX } \\
\text { SMP Negeri } \\
5 \text { Bengkulu } \\
\text { Selatan }\end{array}$ & $\begin{array}{l}\text { Onsilia } \\
\text { jurnal } \\
\text { ilmiah } \\
\text { BK }\end{array}$ & $\begin{array}{l}\text { Mendeskripsik } \\
\text { an pengaruh } \\
\text { layanan } \\
\text { bimbingan } \\
\text { kelompok } \\
\text { dengan teknik } \\
\text { self } \\
\text { management } \\
\text { terhadapat } \\
\text { pemanfaatan } \\
\text { waktu } \\
\text { senggang siswa } \\
\text { kelas IX A } \\
\text { SMP Negeri } 5 \\
\text { Kota Bengkulu }\end{array}$ & $\begin{array}{l}\text { penelitian } \\
\text { eksperimen } \\
\text { dengan } \\
\text { desain } \\
\text { penelitian } \\
\text { one grup } \\
\text { pretest dan } \\
\text { postest. }\end{array}$ & $\begin{array}{l}\text { Hasil } \\
\text { penelitian ini } \\
\text { menunjukkan } \\
\text { adanya } \\
\text { peningkatan } \\
\text { yang } \\
\text { signifikan } \\
\text { pengaruh } \\
\text { bimbingan } \\
\text { kelompok } \\
\text { untuk } \\
\text { meningkatkan } \\
\text { pemanfaatan } \\
\text { waktu } \\
\text { senggang } \\
\text { siswa. Hal ini } \\
\text { dapat dilihat } \\
\text { dari hasil } \\
\text { pengujian } \\
\text { hipotesis } \\
\text { dengan hasil } \\
\text { uji t -19,585, } \\
\text { nilai sig } \\
\text { sebesar } 0,000 \\
\text { (<0,05) maka } \\
\text { Ho ditolak }\end{array}$ \\
\hline $\begin{array}{l}\text { Wahyu } \\
\text { Riyanto, } \\
\text { Yusmansyah, } \\
\text { Diah }\end{array}$ & $\begin{array}{l}\text { Meningkatka } \\
\mathrm{n} \\
\text { Kemampuan } \\
\text { Manajemen }\end{array}$ & $\begin{array}{l}\text { Jurnal } \\
\text { FKIP } \\
\text { Unila }\end{array}$ & $\begin{array}{l}\text { meningkatkan } \\
\text { kemampuan } \\
\text { manajemen } \\
\text { waktu belajar }\end{array}$ & $\begin{array}{l}\text { pre- } \\
\text { experimental } \\
\text { designs } \\
\text { dengan }\end{array}$ & $\begin{array}{l}\text { Hasil } \\
\text { penelitian } \\
\text { menunjukkan } \\
\text { bahwa }\end{array}$ \\
\hline
\end{tabular}




\begin{tabular}{|c|c|c|c|c|c|}
\hline $\begin{array}{l}\text { Ustaminingsi } \\
\text { h / } 2019\end{array}$ & $\begin{array}{l}\text { Waktu } \\
\text { Belajar } \\
\text { Menggunaka } \\
\text { n Bimbingan } \\
\text { Kelompok } \\
\text { Pada Siswa } \\
\text { SMA }\end{array}$ & & $\begin{array}{l}\text { siswa } \\
\text { menggunakan } \\
\text { bimbingan } \\
\text { kelompok pada } \\
\text { siswa di SMA } \\
\text { Negeri } 1 \\
\text { Bandar } \\
\text { Sribhawono, } \\
\text { Lampung } \\
\text { Timur. }\end{array}$ & $\begin{array}{l}\text { teknik one } \\
\text { group pretest } \\
\text { postest. }\end{array}$ & $\begin{array}{l}\text { analisis data } \\
\text { menggunakan } \\
\text { uji wilcoxon } \\
\text { diperoleh } \\
\text { angka } \\
\text { probabilitas } \\
\text { adalah } 0.012 \\
<0.05 \text { maka } \\
\text { Ho ditolak } \\
\text { dan Ha } \\
\text { diterima. }\end{array}$ \\
\hline $\begin{array}{l}\text { Siti Zaenab, } \\
\text { Kasyful } \\
\text { Anwar,Amina } \\
\text { h / } 2020\end{array}$ & $\begin{array}{l}\text { Bimbingan } \\
\text { kelompok } \\
\text { dengan } \\
\text { Teknik focus } \\
\text { group } \\
\text { discussion } \\
\text { untuk } \\
\text { mengurangi } \\
\text { persepsi } \\
\text { negative } \\
\text { siswa } \\
\text { terhadap } \\
\text { bimbingan } \\
\text { konseling di } \\
\text { MTS } \\
\text { Pangeran } \\
\text { Antasari }\end{array}$ & $\begin{array}{l}\text { Jurnal } \\
\text { Mahasisw } \\
\text { a An-nur } \\
\text { Vol } 6 \text { No } \\
3\end{array}$ & $\begin{array}{l}\text { Mengurangi } \\
\text { persepsi negatif } \\
\text { siswa terhadap } \\
\text { Bimbingan dan } \\
\text { Konseling di } \\
\text { Sekolah Kelas } \\
\text { VIII B MTs } \\
\text { Pangeran } \\
\text { Antasari } \\
\text { dengan focus } \\
\text { group } \\
\text { discussion } \\
\text { dalam layanan } \\
\text { bimbingan } \\
\text { kelompok }\end{array}$ & $\begin{array}{l}\text { Eksperiment } \\
\text { al design, } \\
\text { yaitu one- } \\
\text { group pretest } \\
\text { dan posttest, } \\
\text { pretest }\end{array}$ & $\begin{array}{l}\text { menunjukkan } \\
\text { sebelum } \\
\text { diberikan } \\
\text { teknik focus } \\
\text { group } \\
\text { discussion } \\
\text { dalam } \\
\text { penggunaan } \\
\text { layanan } \\
\text { bimbingan } \\
\text { kelompok } \\
\text { rata-rata } \\
\text { skornya } \\
\text { adalah } 198 \\
\text { (52\%) dan } \\
\text { sesudah } \\
\text { diberikan } \\
\text { focus group } \\
\text { discussion } \\
\text { dalam } \\
\text { penggunaan } \\
\text { layanan } \\
\text { bimbingan } \\
\text { kelompok } \\
\text { maka } \\
\text { diketahui } \\
\text { hasilnya } \\
\text { adalah } \\
\text { sebanyak } \\
\text { rata-rata } 187 \\
\text { (49\%). }\end{array}$ \\
\hline $\begin{array}{l}\text { Aini } \\
\text { Purnamasari, } \\
\text { Suroso / } 2020\end{array}$ & $\begin{array}{l}\text { Time } \\
\text { management } \\
\text { to reduce } \\
\text { delay in } \\
\text { middle } \\
\text { school }\end{array}$ & $\begin{array}{l}\text { ICECRS } \\
\text { Umsida }\end{array}$ & $\begin{array}{l}\text { untuk } \\
\text { mengetahui } \\
\text { efektivitas } \\
\text { pemberian } \\
\text { bantuan } \\
\text { manajemen }\end{array}$ & $\begin{array}{l}\text { menggunaka } \\
\mathrm{n} \text { subjek } \\
\text { penelitian } \\
\text { tunggal } \\
\text { atau single } \\
\text { subject }\end{array}$ & $\begin{array}{l}\text { Berdasarkan } \\
\text { dari } \\
\text { observasi, } \\
\text { wawancara } \\
\text { dan } \\
\text { dokumentasi }\end{array}$ \\
\hline
\end{tabular}




\begin{tabular}{|l|l|l|l|l|}
\hline students & & $\begin{array}{l}\text { waktu, untuk } \\
\text { mengurangi } \\
\text { intensitas } \\
\text { keterlambatan } \\
\text { pada siswi } \\
\text { kelas VII. }\end{array}$ & & $\begin{array}{l}\text { diperoleh } \\
\text { hasi bahwa } \\
\text { terdapat } \\
\text { faktor } \\
\text { internal dan } \\
\text { eksternal } \\
\text { yang } \\
\text { mempengaru } \\
\text { hi } \\
\text { seringkali Z } \\
\text { terlambat ke } \\
\text { sekolah. }\end{array}$ \\
\hline
\end{tabular}

\section{PEMBAHASAN}

Berdasarkan analisis artikel diperoleh bahwa layanan bimbingan kelompok dapat mempengaruhi dan meningkatkan persepsi maupun keterampilan siswa dalam meningkatkan pemahaman persepsi maupun keterampilan learning time management peserta didik satuan pendidikan SMP dan SMA. Hal tersebut dapat dijlaskan dalam uraian pembahasan secara kualitatif dari masing-masing artikel.

Penelitian pertama dilakukan oleh (Ulfa Luthfiyanti, Supardi 2020). Data yang diperoleh dari rerata hasil pretest kelompok eksperimen berkisar antara 69,0 hingga 77,1 dengan peningkatan sebesar 8,1. Peningkatan 0,8 tercatat pada kelompok kontrol dari 68,5 menjadi 69,0. Selisih antara kelompok eksperimen dan kelompok kontrol adalah 7,3. Hasil analisis data menunjukkan perbedaan antara kelompok uji yang dilakukan dalam bentuk bimbingan kelompok dengan bantuan permainan simulasi teknis dan kelompok kontrol yang tidak mendapat perlakuan. Penanganan 5 sesi dengan game simulasi. Dari data di atas dapat dikatakan bahwa kepemimpinan kelompok melalui permainan simulasi teknis dapat meningkatkan manajemen waktu pada siswa kelas XII SMA Negeri 9 Semarang.

Penelitian kedua dilakukan oleh (Yeni Rahma Nanda, Syahriman n.d.), diperoleh hasil penelitian bahwa Penggunaan waktu luang siswa setelah bimbingan kelompok kelompok menggunakan teknik self-management yang diukur dalam post-test memiliki presentase sebesar $80 \%$, bahkan dua dari 10 siswa dalam kategori sedang memiliki presentase sebesar 20\%. Dan tidak ada lagi siswa yang termasuk dalam kategori rendah. Dari hasil tersebut dapat dikatakan bahwa penggunaan waktu luang siswa meningkat menjadi 65,5 poin pada pre-test dan 94,5 poin pada post-test. Hasil post-test menunjukkan angka tersebut meningkat secara signifikan, terbukti dengan penggunaan waktu yang didukung dengan pemberian 
materi pengabdian kepada kelompok dan komitmen kepemimpinan kelompok terhadap praktik manajemen diri.

Penelitian ketiga dilakukan oleh (Wahyu Riyanto, Yusmansyah 2020), menmperoleh hasil rata-rata skor manajemen hasil belajar siswa sebesar 118 dengan menggunakan pre-test sebagai pengukurnya. Dari hasil tersebut menunjukkan bahwa nilai belajar manajemen waktu siswa termasuk ke dalam golongan yang sedang. Hasil dari posttest dari sembilan subjek mendapatkan hasil rata-rata nilai manajemen waktu belajar peserta didik menjadi 151, dimana hasilnya ada peningkatan setelah dilakukan layanan bimbingan kelompok sebanyak empat kali pertemuaan. Hasil ini tergolong pada kategori rata-rata manajemen waktu belajar siswa yang tinggi. Siswa kelas X SMA N 1 Bandar Sribhawono yang dijadikan sebgai subjek penelitian mengalami peningkatan yang cukup signifikan dalam hal manajemen waktu belajarnya berdasarkan dari hasil analisis data yang dilakukan. Dapat disimpulkan bahwa terjadi peningkatan manajemen waktu belajar siswa setelah melalui layanan bimbingan kelompok, dengan hasil data penelitian yang didapatkan sebesar $0,012(0,05<0,012)$.

Penelitian keempat dilakukan oleh (Zainab and Anwar 2020) diperoleh hasil dari data pretest dan posttet yang menggunakan Wilcoxon pada aplikasi SPSS menunjukkan hasil Asymp.Sig sebanyak 0.012. Oleh karena itu, hasil stufdi menunjukkan bahwa Wilcoxon \& lt; 0,05 ditolak (Ho) dan diterima (Ha) karena sebelum dan sesudah konseling di sekolah dengan teknik FGD mendapat persepsi negative dari siswa. Berarti untuk mengurang persepsi negative siswa terhadap konseling dapat menggunakan layanan konseling kelompok secara terfokus berdasarkan hasil belajar pre-test sebelum pengajaran teknik diskusi kelompok I tidak. Kategori nilai interval pre-test dan post-test meliputi 3 siswa pada golongan penilaian sedang dan 5 siswa pada golongan penilaian rendah. Setelah dilakukan post-test, delapan orang dengan nilai terendah berubah. Nilai hasil pre-test ialah $198(52 \%)$ dan nilai hasil posttest ialah 49 (3\%). Oleh karena itu, layanan konseling kelompok melalui teknik focus group discussion dapat menurunkan pandangan negatif siswa kelas VIII MTs Pangeran Antasari.

Penelitian kelima dilakukan oleh, (Purnamasari ASuroso S 2020) ditemukan bahwa di SMP X, kami menemukan bahwa siswa kelas 7 yang berinisial Z, seorang wanita lebih sering terlambat daripada teman-temannya, dengan rata-rata keterlambatan 5 kali dalam sebulan. Berdasarkan data awal guru Bimbingan dan Konseling, factor internal seperti terlambat bangun, dan factor eksternal seperti kecemasan saat akan berangkat ke sekolah sangat memperngaruhi keterlambataan $\mathrm{Z}$. 
$\mathrm{Z}$ mengalami masalah keterlambatan karena manajemen waktu $\mathrm{Z}$ menjadi buruk dan disebabkan oleh factor yang ada maupun juga lingkungan keluarga yang masih kurang mendukung. Berdasarkan penjelasan tersebut, penelitian ini dilaksanakan untuk mengevaluasi keefektifan dukungan manajemen waktu kepada si Z. Gea's Fischer [6] menjelaskan bahwa pengembangan dan implementasi manajemen waktu hasil pada tahap awal implementasi tidak selalu terlihat, tetapi ketika diterapkan secara konsisten, hasilnya sangat mengesankan. Untuk memperoleh hasil yang lebih positif di masa depan,sangat penting untuk mendapatkan hasil di masa depan dengan manajemen waktu saat ini.Z sebagai subjek orangtuanya merupakan partisipan pada penelitian kali ini.Pengumpulan data pada penelitian ini menggunakan metode observasi, metode wawancara, dan dokumentasi. Observasi pada penelitian kali ini berkaitan dengan tingkah laku subjek saat mengikuti pelatihan dan pembelajaran, serta pada saat istirahat sekolah.Untuk memperoleh suatu gambaran mengenai factor yang mempengaruhi keterlambataan yang terjadi, dilakukan wawancara antara penguji dengan orang tua dan juga guru.. Dokumen yang didapatkan pada penelitian ini ialah peraturan sekolah dan juga daftar siswa yang terlambat. Berdasar dari data yang didapat, peneliti memutuskan langkah mana yang akan diambil sebagai tindakan intervansinya.

Intervensi tersebut dilakukan dengan $\mathrm{Z}$ sebagai penguji dan induk penguji. Intervensi dengan menemani subjek pada waktu yang jelas dan tertulis dari kegiatan sehari-hari sementara orang tua subjek psikoedukasi. Berdasarkan observasi, wawancara, dan hasil yang diperoleh, didapatkan faktor internal maupun eksternal yang sering mempengaruhi keterlambatan $\mathrm{Z}$ di sekolah. Faktor internalnya adalah $\mathrm{Z}$ dan tidak ada waktu tetap untuk aktivitasnya. Z tidak bisa bangun dari tempat tidur, butuh waktu lama untuk bersiap ke sekolah, dan $\mathrm{Z}$ mengerjakan pekerjaan rumahnya di pagi hari sebelum pergi ke sekolah. Z juga mempunyai pola tidur malam yang tidak teratur. Faktor eksternal dari keterlambatan $\mathrm{Z}$ adalah kurangnya faktor komunikasi dalam keluarganya, antara sekolah $\mathrm{Z}$ dan dengan kemacetan pagi hari. Ketika $\mathrm{Z}$ dihukum karena terlambat, $\mathrm{Z}$ cenderung menerima pikiran dan perasaannya serta tidak terbuka dengan keluarganya.

Berdasar dari beberapa hasil intervensi yang telah terlaksana, disimpulkan bahwa intervensi yang sudah dilakukan pada klien memiliki hasil yang sangat baik jika subjek mengalami perubahan pola pikir dan perilaku setelah pendampingan yang dilakukan, manajemen waktu dapat meningkat. Dalam hal ini intervensi yang dilakukan sudah sangat baik dan sangat sesuai dengan tujuan intervensinya. Artinya klien mampu mengatur waktu yang dimiliki dengan cukup baik. Hasil campur tangan orang tua juga menunjukkan hasil 
yang sudah baik. Orang tua lebih paham terhadap masalah yang mereka hadapi di sekolah dan dalam hal penentuan sikap mereka terhadap dukungan yang didapatkan untuk mengentaskan masalah yang berkaitan dengan keterlambatan kedatangan di sekolah

Berdasarkan uraian artikel diatas menunjukkan hasil layanan bimbingan kelompok memiliki pengaruh yang besar dan juga signifikan terhadap keterampilan time management peserta didik diberbagai satuan pendidikan mulai SMP - SMA. Layanan bimbingan kelompok terbukti dapat meningkatkan keterampilan peserta didik dalam hal time management. Penerapan dari teknik focus group discussion ini, terbukti mampu mengurangi persepektif negatif siswa. Dengan Teknik focus group discussion Ini membangkitkan semangat siswa karena merekamendapatkan suatu pemahaman yang lebih baik mengenai tujuan masalah pembelajaran dan pemahaman yang lebih dalam tentang bagaimana memecahkan masalah yang diangkat melalui proses bimbingan secara bertingkat

\section{SIMPULAN}

Menggunakan Tehnik Focus Discussion Group dapat memberi kesempatan kepada anggota kelompok untuk mengemukakan permasalahan, mengemukakan dan memahami permasalahan antar anggota kelompok, berbagi saran dan cara penyelesaian masalah dan mengembangkan ketrampilan time manajement. Melalui hasil studi tersebut didapatkan kesimpulan bahwa hal tersebut dapat meningkatkan belajar manajemen waktu yang cukup relevan setelah diberikan layanan bimbingan kelompok dengan menggunakan tehnik focus discussion group yang diharapkan meningkatkan minat ketrampilan siswa,karena dengan adanya pendekatan tersebut memiliki pengaruh yang positif dan signifkan terhadap ketrampilan peserta didik agar peserta didik nantinya dapat mengontrol dan mengelola waktu sebaik mungkin..

\section{DAFTAR PUSTAKA}

Gunawan, Ronny. 2018. "Peran Tata Kelola Layanan Bimbingan Dan Konseling Bagi Siswa Di Sekolah.” Jurnal Selaras : Kajian Bimbingan Dan Konseling Serta Psikologi Pendidikan 1(1):1-16. doi: 10.33541/sel.v1i1.766.

NISA BELLA, VIVIEN. 2019. "PENERAPAN BIMBINGAN KELOMPOK DENGAN METODE KISAH DALAM UPAYA MENINGKATKAN MOTIVASI BELAJAR PADA SANTRI PONDOK PESANTREN AL-ITTIFAQIAH INDRALAYA.” UIN Raden Fatah Palembang 22-59.

Purnamasari ASuroso S. 2020. "Time Management to Reduce Delays in Middle School Students." Proceedings of the ICECERS 8. doi: 10.21070/icecrs2020409.

Ulfa Luthfiyanti, Supardi, dan Agus Setiawan. 2020. "PENGARUH LAYANAN 
BIMBINGAN KELOMPOK DENGAN TEKNIK SIMULATION GAMES UNTUK MENINGKATKAN MANAJEMEN WAKTU BELAJAR.” 15(September):27-35.

Wahyu Riyanto, Yusmansyah, Diah Utaminingsih. 2020. "Meningkatkan Kemampuan Manajemen Waktu Belajar Menggunakan Bimbingan Kelompok Pada Siswa SMA Improove."

Waluyati, Made. 2020. "Penerapan Fokus Group Discussian (FGD) Untuk Meningkatkan Kemampuan Memanfaatkan Lingkungan Sebagai Sumber Belajar." Jurnal Edutech Undiksha 8(1):80. doi: 10.23887/jeu.v8i1.27089.

Yeni Rahma Nanda, Syahriman, Vira Afriyati. n.d. "PENGARUH LAYANAN BIMBINGAN KELOMPOK DENGAN TEKNIK SELF MANAGEMENT TERHADAP PEMANFAATAN WAKTU SENGGANG SISWA KELAS IX A SMP NEGERI 5 BENGKULU SELATAN Yeni.” Consilia 4(3):283-92.

Zainab, Siti, and Kasyful Anwar. 2020. "Jurnal Mahasiswa BK An-Nur : Berbeda, Bermakna , Mulia Volume 6 Nomor 3 Tahun 2020 Tersedia Online: Https://Ojs.UniskaBjm.Ac.Id/Index.Php/AN-NUR BIMBINGAN KELOMPOK DENGAN TEKNIK FOCUS GROUP DISCUSSION KONSELING DI MTS PANGERAN ANTASARI Dipublikasikan O.” 6:1-4. 